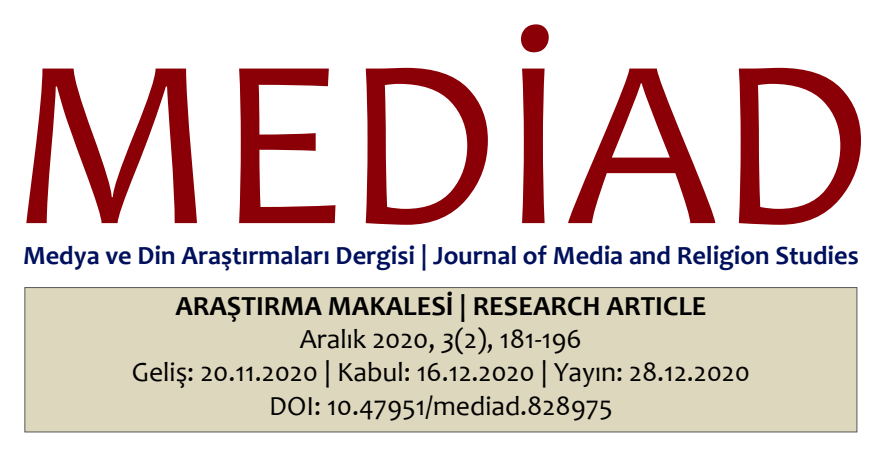

\title{
İslam Karşıtı Söylemlerin Avrupa Medyasındaki İzleri
}

\author{
Mustafa TEMEL* \\ Ömer Faruk KOÇAK**
}

\begin{abstract}
Öz
Günümüz temel bilgi kaynaklarından olan kitle iletişim araçları aynı zamanda ötekinin kurgulandığı, ideolojik amaçlarla nefret söyleminin inşa edildiği ve algı yönetiminin yapıldığı bir zemin olma özelliği tașımaktadır. Bu durumun somut izlerini medyanın İslam ve Müslümanlar ile ilgili içeriklerinde gözlemlemek mümkündür. Tarihsel bir oryantalist ön yargı taşıyan, ayrımcılığı ve yabancı düşmanlığını sürdüren Batı medyası, üretmiş olduğu içeriklerle İslamofobik tutum ve eylemlerin artış göstermesine sebep olabilmektedir. Bu çalışmada da Avrupa medyası örneğinde, medyanın İslam ve Müslümanlar ile ilgili oluşturmuş olduğu içerikler incelenmiştir. İslamofobinin medyatik üretimine ilişkin bir sorgulamayı içeren ve 16 Avrupa ülkesindeki farklı medya türlerinde yer alan güncel meselelerde i̇slam'ın ve Müslümanların temsil/sunum şeklini sorgulayan çalışmada nitel yönelimli içerik analizi yöntemi kullanıımıştır. Araştırma sonucunda, Avrupa'daki birçok yazılı ve görsel medyada, İslam ve Müslümanlara yönelik tarihsel süreçten beslenen negatif bir ton taşıyan ve İslam karşıtlığı içeren ifadelerin/anlatımların/kurguların sıkça yer aldığı belirlenmiştir.
\end{abstract}

Anahtar Kelimeler: İslamofobi, İslam Karşıtlı̆̆ı, Oryantalizm, Medya, Siyaset

\section{Traces of Anti-Islamic Discourses in European Media}

\begin{abstract}
Mass media, one of the current primary information source, is a platform in which other is fictionalized, hate speech is built for ideological purposes and perception management is made. This can be traced concretely in the contents produced by media regarding Islam and Muslims. The western media having a historical orientalist prejudice, maintaining discrimination and xenophobia has caused an increase in Islamophobic attitudes and actions with the contents it produced. In this study, the contents generated by media regarding Islam and Muslims were examined based on the European media case. The content analysis method was administrated in this qualitative study, including an inquiry into the media production of Islamophobia and questioning the way Islam and Muslims are represented/presented in current issues in different media types in 16 European countries. This study concluded that the statements/ expressions/ fictions caused by historical process regarding Islam and Muslims, having negative manner and including Anti-Islamism are used frequently in many print and visual media in Europe.
\end{abstract}

Keywords: Islamophobia, Anti-Islamism, Orientalism, Media, Politics

ATIF: Temel, M. ve Koçak, Ö. F. (2020). İslam karşıtı söylemlerin Avrupa medyasındaki izleri. Medya ve Din Araştırmaları Dergisi (MEDIAD), 3(2), s. 181-196.

* Dr. Öğr. Üyesi, Erciyes Üniversitesi, e-mail: mustafatemel@erciyes.edu.tr| orcid.org/0000-0003-0828-0660

** Arş. Gör. Dr., Erciyes Üniversitesi, e-mail: okocak@erciyes.edu.tr| orcid.org/0000-0002-0152-5875 


\section{Giriş}

Bilgi kaynağı olarak işlev gören kitle iletişim araçları aynı zamanda eğitme, eğlendirme misyonu ile bireylerin gündelik hayatını etkileyen, belirleyen bir öneme sahiptir. Bununla birlikte, herkese hitap edebilen içerik üreten medyatik araçlar aynı zamanda ideolojik/ekonomik sebeplerden dolayı bilgileri manipüle etme, algı oluşturabilme ve yönlendirme de yapabilmektedir.

İdeoloji aktarımı ve tutum değiştirme aygıtı olarak işlev gösteren; enformasyonu toplumu etkileme ve yönlendirme amacıyla kontrol altında tutan medya, ürettiği içerikler ile toplumsal kontrol sürecinde araç olarak kullanılabilmektedir (Eagleton, 1996, s. 61). Bu noktada da imge ve algı üretimini bilinçli olarak kontrol eden ve oluşturduğu kurgusal anlatımlarla ideolojik amaçları perdeleyebilen medya, gerçeklikleri yeninden inşa edebilmektedir. Bu amaçlarla medya kişileri, toplumları, ideolojileri ve diğer unsurları farklılaştıran, ötekileştiren bir söylemi de üretebilmektedir. Dolayısıyla medya, ötekileştirilenlerin tasvir edildiği, yeniden inşa edildiği ve ötekilerin karşılaştığı bir platform (Alver, 2000, s. 78), bir mecra konumundadır. Bu bakımdan tarihsel süreçte uluslararası bilgi üretim ve kontrolünü elinde tutan Batı, kendisini "ben" algısı ile özne konumuna koyarken, Doğu'yu, özelde de İslam'ı ötekileștirebilecek bir nesne konumuna indirgeyen bir bakış açısı ile medyatik içerikler üretmiştir (Sözen, 1999, s. 136). Bu kategorilendirme, Batı-Doğu ilişkilerinin tarihsel süreçten günümüze gelen siyasal, sosyal ve ekonomik olaylarında görünür olmaktadır. Bu süreçlerde Batı, özelde İslam'a yönelik negatif anlam ve tutumları sürekli güncel tutmuş, söz konusu anlatımların siyasal alanda işlevsellik kazanabilmesi amacıyla bir öteki/düşman inşa etmiştir.

İslam'ın Avrupa'da yaygınlaşmaya başlaması, Batı ve Doğu ülkeleri arasında yaşanan savaşlar ve İslam ülkelerinin güçlenerek fetih alanlarını genişletmesi, Müslümanların Avrupa'ya göçmen olarak yerleșmeye başlaması ile Avrupa'da Müslüman nüfusun artması, İran İslam Devrimi'nin politik amaçlarla küresel bir dille okunması, Sovyetler Birliği'nin çökmesi ile Batı'nın ideolojik bir düșman üretimini gerekli görmesi, 11 Eylül 2001 tarihinde yaşanan olaylar, İslam'a yönelik kurgusal olarak üretilen negatif anlatımları güncel tutmuş ve bu tarihsel olaylardan İslam'a ve Müslümanlara yönelik terör yanlısı, irticacı, anti demokratik, gerici, ilkel, barbar, radikal, çağdışı, otoriter, saldırgan sıfatları üretilmiştir.

Batı'nın İslam'a ve Müslümanlara yönelik kullanmıs olduğu bu dil, i̇slam'ın yeterince anlaşılamamasını, İslam'a ve Müslümanlara korku ile yaklaşılması gerektiği anlamını ortaya çıkarmıştır. Bu açıdan bakıldığında İslam'ı tanıtan kültürel araçların başında gelen televizyon, gazete ve dergilerde i̇slam nasıl yer ediniyorsa toplum algısı da o perspektifte şekillenmiştir (Said, 2008, s. 121). Çünkü günümüz toplumlarında medya; olayları, hikâyeleri, kültürleri ve bireyleri tasvir etmede ve yeniden anlatmada benzersiz bir güce sahiptir ve bu yüzden medyada sunulan temsiller izleyiciler üzerinde tartışılmaz bir doğruluk etkisi oluşturabilmektedir (Cottle, 2000, s. 100). Bu sebeple dünyada medyanın sunumundan dolayı, İslam/Müslüman gerçekliği gazete, dergi ve televizyonlardaki imajlarla bir tutulmaktadır (Uluç, 2009, s. 332).

Literatürde yer alan çalışmaların da gösterdiği gibi i̇slam ve Müslümanlara odaklanan haberler, medyada olumsuz bir şekilde çerçevelenmekte ve terörizm, radikalizm, şiddet, anti-demokratik görünümler gibi sınırlı konularda sabit kalmakta, İslam'a ve Müslümanlara dair olumlu eylemler ve kritik konular (Müslümanlara yönelik gerçekleşen ırkçוık ve ayrımcılık) ise medyada yeteri kadar temsil bulamamaktadır (Hassan; Azmi; Abubakar, 2017, s. 113). Bununla birlikte Poole'e göre (2003, s. 217); batı medyasında İslamofobik tezahür ve anlatımlar üç temada özetlenmektedir. Bunlardan ilkine göre, Müslümanlar "öteki" ve Batı medeniyetine yönelik bir tehdit olarak temsil edilmekte, ikincisine göre, Müslümanlar liberal ve ana akım değerler için bir tehlike olarak ifade edilmekte ve son olarak Müslümanların sahip oldukları kültürel ve dini farklılıkların Müslüman olmayanlar ile sosyal ve politik gerilime sebep olacak birer unsur olduğu ifade edilmektedir. Medyada, Avrupalıların hafızalarındaki klișelerle, metaforlarla sıkça (Gökçe ve Gökçe, 2015, s. 71) yer bulan İslam ve Müslümanlar, 
enformasyon kontrolünü ellerinde tutamadıkları için alternatif söylemler de geliştirememekte ve bunun sonucunda İslam ve Müslümanlar ile ilgili hâkim medyadaki negatif söylemler artmaktadır. Dolayısıyla, bu ve benzeri bakış açılarının bir sonucu olarak üretilen, Batı medyasında olumsuz şekilde sunulan şeylerin Müslümanları ve İslam'ı temsil etmediğini, bunların ancak politik amaçlarla üretilen içerikler olduğunu söylemek mümkündür (Said, 2008, s. 245).

Gazete, dergi, televizyon ve internet gibi araçlarda İslam dini klişe temsillerle sunulup, olumsuz bir çerçevede inşa edilirken, İslam ve Müslümanlara dair olumlu imajlara medyada yer verilmemektedir (Lean, 2015, s. 136). Özellikle geleneksel medya ile sürdürülen, tarihsel ön yargı ve ayrımcılıktan kaynaklanan bu anlatılar internet teknolojilerinin gelişmesi ile birlikte biçim değiştirerek daha fazla görünür olmaya başlamıştır. İnternet üzerinden oluşturulan bu imaj ile İslam belirli kişi ve grupların davranışları ile eşleştirilmiş ve tek taraflı olarak sunulmuştur. İnternetin gelişimi ile ortaya çıkan sosyal medya araçlarında i̇slam'a karşı ön yargılı olan kişilerin/kurumların bilinçli bir şekilde içerik üretmesi de İslam karşıtı söylemlerin artmasına sebep olmuştur. Bu yönüyle de sosyal medyanın, İslam karşıtı tutum ve eylemlerinde gücünü artırmada geleneksel medyadan daha etkin olduğu düşünülmektedir (Esposito, 2013, s. 29-30).

Görülebileceği üzere, İslam dinine ve Müslümanlara karşı duyulan ön yargıya ve ayrımcılığa dayalı korkuyu ifade eden İslamofobinin son zamanlarda artmasında ve küresel bir problem haline gelmesinde kitle iletişim araçlarının görünür bir önemli etkisi bulunmaktadır. Bu bağlamda, siyasal, sosyal/kültürel ve ekonomik alanlarda ayrımcılığa, ötekileştirmeye, dışlamaya sebep olan, yabancı düşmanlığına dayanan ve aynı zamanda kurumsal bir şekilde kültürel ırkçlığı ifade eden, nefret söylemi içeren İslam karşıtı tutumlar ve İslamofobik eylemler birçok disiplin perspektifinde çalıșılması gereken bir alanı ifade etmektedir. Fakat özellikle medya araçlarının tutum ve algıları belirleme/yönetme konusundaki gücü ele alındığında, bahsedilen İslam karşıtlığının oluşmasında medyanın etkisi tartışılması gereken bir mesele olarak karşımıza çıkmaktadır.

Çalışmada da, İslam'ın/Müslümanların temsili sorgulanarak, küresel siyasal, sosyal, kültürel, ekonomik ve teolojik bir problem haline gelen İslamofobiye ilişkin iletişimsel bir perspektif sunmak amaçlanmıştır. Bu bakımdan, içerik analizi yönteminin kullanıldığı çalışmada İslam'ın Avrupa medyasındaki temsili incelenmiş ve bu temsil neticesinde ortaya çıkabilecek İslam karşıtlığı söylemleri tartışılmış ve Avrupa'da artan İslamofobik eylemlerde medyanın etkisine ilişkin bir perspektif sunulmuştur.

\section{Araştırma: İslam Karşıtı Söylemlerin Avrupa Medyasında İzleri}

\subsection{Araştırmanın Amacı ve Önemi}

Kitle iletişim araçları İslam ve Müslüman karşıtı ırkçılığın, ön yargının, tehdit algısının, nefret söyleminin üretilip yaygınlaştııılmasında ve bu söylemlerin normalleştirilme sürecinde önemli bir rol oynamaktadır. Özellikle Avrupa'da yaşayan ve İslam dinine inanan insanların sosyal, siyasal ve kültürel alanlarda bu sebepten dolayı mağdur durumda olduğu göz önüne alındığında, bu ülkelerdeki medya araçlarının İslam'a ve Müslümanlara yaklaşımı oldukça önem taşımaktadır.

Medya ve íslamofobi konusunu ele alan çalışmalara ek olarak; gazete, televizyon ve internet gibi kitle iletişim araçlarının farklı türlerine ait örnekleri bir arada inceleyen bu çalışmada Avrupa'daki birçok ülkeden örneklere yer verilmesi İslamofobinin mevcut durumunun tespitine ve bu problemin güncel durumuna ilişkin bir çerçeve sunacaktır. Bununla birlikte, çalışmada çeşitli kurum ve kuruluşlar ${ }^{1}$ tarafından yıllık olarak hazırlanan İslamofobi raporlarında da görüleceği üzere, İslamofobinin azalmayan, tersine, tekrarlanan, şiddeti ve etkileri oldukça hızlı bir şekilde artan bir problem olmasına ve medyanın da bu söylemi yaygınlaştıran, bu problemi daha ileri bir seviyeye taşımasına ilişkin güncel bir sorgulama yapılacaktır. 


\subsection{Araştırmanın Kapsam ve Sınırlılıkları}

Siyaset, Ekonomi ve Toplum Araştırmaları Vakfı (SETA) tarafından 2019 yılında "European Islamophobia Report 2019" başlı̆̆ı ile yayımlanan raporun "Islamophobia in the Media" isimli kısmında yer alan (European Islamophobia Report, 2019, s. 5056), "Infografik: Medyada İslamofobi” başlı̆ı̆ ile de web sitesinde yayınlanan raporda, Avrupa'daki medya araçlarında İslam ve Müslümanlar ile ilişkilendirilebilen içeriklere yer verilmiştir. ilgili raporun Avrupa'daki birçok ülkeye ait genel bir örneklem kümesi sunması sebebiyle, araştırma kapsamında, raporda yer alan İslam ve Müslümanlar ile ilişkilendirilebilecek içeriklerin sunum şekli ve içerik değerlendirmesi yapılmıştır.

Raporda yer alan ülkelere ait medya içeriklerinin incelendiği çalışmada, her ülkeden bir örnek medya içeriğine yer verilmiştir. Raporda yer alan bu örneklerin hepsi çalışmanın inceleme kapsamına alınmış, sadece bir örnek, çalışma konusu ile ilişkisinin belirlenememesi sebebiyle kapsam dışı bırakılmıştır.

2019 yılına ait verileri inceleyen çalışmada içeriklerin tespit edildiği medya araCı göz önüne alınmıştır. Bu bağlamda içeriklerin rapor, haber, yazı dizisi vb. şeklinde gazete, televizyon ve internet siteleri gibi birçok medya türünde yer aldığı belirlenmiştir. Dolayısıyla araştırmada, yazılı ve görsel-işitsel medyaya ilişkin örneklerin yer aldığını söylemek mümkündür. Çalışma kapsamında Avrupa'da yer alan 16 farklı ülkeye ait 16 medya içeriği incelenmiştir. Bu içeriklerin 11 tanesi görsel-işitsel veri olup, değerlendirmeye dahil edilmiştir.

\subsection{Araștırmanın Yöntemi}

Araştırma kapsamında incelenecek olan rapordaki verilere ilişkin genel bir ön okuma yapılmış, ardından metin içerisindeki anlamları nicel ve nitel verilerle belirlemek, aynı zamanda metinlerdeki hâkim anlama yönelik çıkarımlar yapabilmek amacıyla nitel yönelimli içerik analizi yöntemi tercih edilmiştir.

içerik analizi metinlerde yer alan içeriği toplama ve analiz etme tekniği olup, içerik iletebilen sözcükler, anlamlar, semboller, düşünceler, temalar, resimler aracılığı ile herhangi bir iletiye gönderme yapar (Neuman, 2014, s. 466). Kitle iletişim araçlarındaki içeriğe yönelik olarak kullanılan içerik analizi; iletişim içeriğinin çoğunlukla önceden belirlemiş kategoriler çerçevesinde sistematik biçimde incelenmesini ifade eden bir tekniktir (Geray, 2006, s. 147). Belirli biçimde kayıt altına alınmış metinlerin analiz edilmesine dayanan içerik analizi, metnin taşıdığı mesaja ve ilettiği enformasyonla birlikte anlam üzerine odaklanır (Yıldırım, 2015, s. 105). Metinde yer alan niceliksel öğeleri ortaya çıkarttığı gibi kodlar ve temalar aracılığı ile anlamlar üzerine yoğunlaşan içerik analizi (Bal, 2013, s. 181) iletiler/veriler (özellikle medya mesajları) sayesinde topluma iletilen mesajların ve egemen hale getirilmeye çalışılan ideolojilerin ne olduğunu da ortaya çıkarmayı amaçlar (Yaylagül, 2012, s. 8). Bununla birlikte, nicel içerik analizinden farklı olarak nitel yönelimli içerik analizi, sayısal verilerle birlikte nitel veya yorumlayıcı türleri de kullanır ve incelenecek olan unsurları kültürel anlam taşıyan kültürel bir nesne olarak görür (Neuman, 2014, s. 466-467) ve veriler arasındaki bağlamları araştırır. Dolayısıyla içerik analizi yalnızca incelenen materyalin biçimsel yönünü açığa çıkarmakla kalmaz aynı zamanda o materyali ortaya koyan yazarının tutumlarını veya algılarını da tanımlayabilir (Chelimsky, 1989, s. 7).

Bu çalışmada, raporda yer alan medya içerikleri incelendikten sonra, içeriklerde yer alan İslam ve Müslümanlar ile ilişkilendirilerek kullanılan kavramlar, metin içerisindeki kullanım anlamına göre belirlenmiş ve bu kavramların kategorik çerçevesi oluşturulmuştur. Hazırlanan kategorilerin her biri araştırma soruları çerçevesinde nitel yönelimli içerik analizi yöntemiyle incelenmiştir. Ön deneme ve güvenirlik ilkelerine dikkat edilerek raporda yer alan medya içerikleri farklı araştırmacılar tarafından da değerlendirilmiş ve kodlanmıştır. Yapılan ön deneme ve güvenirlik sürecinde elde edilen verilerin büyük oranda benzerlik taşıdığı belirlenmiştir. 


\subsection{Araștırma Soruları}

Çalışma kapsamında hazırlanan ve araştırmanın konusunu sınamaya/ varsayımları test etmeye yarayan araştırma soruları şu şekildedir:

1. İslam ve Müslümanlar ile ilişkilendirilebilecek içeriklerin yer aldığı medya türleri nelerdir?

2. İslam ve Müslümanlar ile ilişkilendirilerek kullanılan kavramlar ve bu kavramların kullanım sıklığı nedir?

2.1. Kavramların kullanımı ile öne çıkarılan temalar nelerdir?

2.2. Kavramların anlatım niteliği ve anlatım biçimi nasıldır? nedir?

2.3. Kavramlar hangi görsellerle birlikte kullanılmıştır ve görsellerin içeriği

\subsection{Bulgular}

Araştırma kapsamında elde edilen bulgular şu şekildedir:

Tablo 1. Araştırma içeriklerinin Belirlendiği Ülkeler

\begin{tabular}{|c|c|c|}
\hline \multicolumn{2}{|c|}{ Ülkeler } \\
\hline Almanya & & Hollanda \\
\hline Arnavutluk & & İspanya \\
\hline Avusturya & & Macaristan \\
\hline Bosna Hersek & & Norveç \\
\hline Hırvatistan & & Sırbistan \\
\hline Çekya & & Slovenya \\
\hline Finlandiya & & Romanya \\
\hline Fransa & & Yunanistan \\
\hline
\end{tabular}

"Islamophobia in the Media" isimli raporda yer alan, İslam ve Müslümanlar ile ilgili içeriklerin yayımlandığı ülkelerin oldukça fazla olduğu görülmektedir. Birçok Avrupa ülkesine ait örneklerin yer aldığı raporda, Müslüman göçmen/mülteci nüfusunun fazla olduğu ülkelere ait içerikler de yer almaktadır.

Tablo 2. içeriklerin Yer Aldığı Medya Türleri

\begin{tabular}{|c|c|c|c|c|c|c|c|c|c|}
\hline $\begin{array}{l}\frac{\grave{d}}{\bar{d}} \\
: \overline{\bar{J}}\end{array}$ & 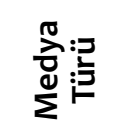 & 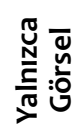 & 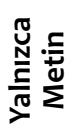 & 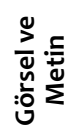 & $\begin{array}{l}\frac{\grave{d}}{d} \\
\stackrel{\bar{y}}{\bar{D}}\end{array}$ & 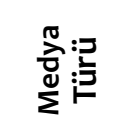 & 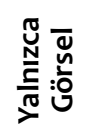 & 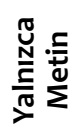 & 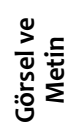 \\
\hline Almanya & Gazete & & $x$ & & Hollanda & Gazete & & & $x$ \\
\hline Arnavutluk & TV & $\mathrm{x}$ & & & İspanya & $\begin{array}{c}\text { Haber } \\
\text { Sitesi }\end{array}$ & & & $x$ \\
\hline Avusturya & Gazete & & $x$ & & Macaristan & $\begin{array}{c}\text { Haber } \\
\text { Sitesi }\end{array}$ & & $\mathrm{x}$ & \\
\hline Bosna Hersek & $\begin{array}{c}\text { Haber } \\
\text { Sitesi }\end{array}$ & & & $x$ & Norveç & $\begin{array}{c}\text { Haber } \\
\text { Sitesi }\end{array}$ & & & $\mathrm{X}$ \\
\hline Hırvatistan & $\begin{array}{c}\text { Haber } \\
\text { Sitesi }\end{array}$ & & & $\mathrm{x}$ & Sirbistan & Gazete & & & $\mathrm{x}$ \\
\hline Çekya & Gazete & & $x$ & & Slovenya & $\begin{array}{l}\text { Haber } \\
\text { Sitesi }\end{array}$ & & & $X$ \\
\hline
\end{tabular}




\begin{tabular}{|c|c|c|c|c|c|c|c|c|c|}
\hline Finlandiya & TV & $X$ & & & Romanya & $\begin{array}{c}\text { Internet } \\
\text { Sitesi }\end{array}$ & & $X$ & \\
\hline Fransa & TV & & & $X$ & Yunanistan & Gazete & & & $X$ \\
\hline
\end{tabular}

Tablo 2'de yer alan verilere göre, raporda yer alan ve incelenen içeriklerin yayımlandığı medya türlerinin oldukça çeșitlilik gösterdiği belirlenmiștir. İncelenen 16 içerikte görsel kullanımının ön plana çıktığı tespit edilmiştir. Araştırma kapsamında raporda yer alan, 6 ülkenin gazete içerikleri, diğer 10 ülkeye ait görsel ve metin kullanımına önem veren televizyon, haber sitesi ve internet içerikleri değerlendirilmiştir.

Tablo 3. Içeriklerde İslam ve Müslümanlar İle İlişkili/ilişsilendirilebilecek Kavramlar

\begin{tabular}{|c|c|c|c|}
\hline Ülkeler & Kavramlar & Ülkeler & Kavramlar \\
\hline Almanya & Domuz Eti & Hollanda & Selefizm \\
\hline Arnavutluk & Kılıç, Minare & İspanya & $\begin{array}{l}\text { Bez Parçası, Başörtüsü, Ka- } \\
\text { dın, Illahi Metinler, }\end{array}$ \\
\hline Avusturya & $\begin{array}{c}\text { Faşist, Kanlı Eylem, Nef- } \\
\text { ret }\end{array}$ & Macaristan & Göçmen \\
\hline $\begin{array}{l}\text { Bosna Her- } \\
\text { sek }\end{array}$ & Cihatçı & Norveç & Aşırıcılar, Cami \\
\hline Hırvatistan & $\begin{array}{c}\text { Acımasızlık, Sinsice, Ka- } \\
\text { dın, Eril, }\end{array}$ & Sirbistan & $\begin{array}{c}\text { İşgal, Cihatçı, Terörizm, } \\
\text { İstila }\end{array}$ \\
\hline Çekya & $\begin{array}{c}\text { Başörtü, Kadın, Zapt Et- } \\
\text { mek }\end{array}$ & Slovenya & Helal Gıda, Domuz eti \\
\hline Finlandiya & $\begin{array}{c}\text { Cinsel Saldırı, Göç, Mül- } \\
\text { teci }\end{array}$ & Romanya & $\begin{array}{c}\text { Kur'an, Para, Dev Müslüman } \\
\text { Şirketi, Haçlı, Şeyh }\end{array}$ \\
\hline Fransa & $\begin{array}{c}\text { Başörtü, Kadın, İhramlı } \\
\text { Erkekler, İslamlaştırılma, } \\
\text { İşgal, Göç, Sindirme, İsti- } \\
\text { la, Sömürgeleşme }\end{array}$ & Yunanistan & İşgal, Terör, Saldırı Korku \\
\hline
\end{tabular}

İncelenen medya içeriklerinde İslam ve Müslümanlarla ilişkili/ilişkilendirilebilen kelime ve kavramlar belirlenmiştir. Kelime ve kavramların belirlenmesinde cümle içerisinde kullanılan bağlam göz önüne alınmıştır. Bu perspektifte, Avrupa medyasında İslam ve Müslümanlar ile ilişkili kullanılan kavramların negatif bir görünüme sahip olduğu belirlenmiştir. Kullanılan kavramlarla, tarihsel süreçten kullanılagelen İslam karşıtı söylem ve anlamların günümüze taşındığını söylemek mümkündür. Anlamsal bağdan koparılmış ve genellikle popüler medya içeriklerinde bilinçli olarak İslam karşıtı propaganda ile kullanılan kelime ve kavramlarla İslamofobik bir söylem oluşturulmaya çalışımıştır. Ayrıca incelenen içeriklerde İslam ve Müslümanlar ile ilişkili/ilişkilendirilebilecek olumlu kavramlar ve anlatımlar tespit edilememiştir.

Tablo 3'de yer alan kavramların belirli bir siyasal/sosyal/ekonomik olaylar ile ilişkili olabileceği ve bu kavramlardan hareketle genel bir medya okuması yapılmasının yanlış olabileceği düşünülebilir. Fakat tabloda yer alan kavramların zaten sürekli olarak İslam karşıtlığı oluşturulabilecek bir anlatımla kullanıldığı, dolayısıyla bu kavramların İslamofobik söylemi sürdürdüğü ifade edilebilir.

Tablo 4. İslam ve Müslümanlar ile iliş̧kili/ilişkilendirilebilecek Kavramların Sayısı

\begin{tabular}{|c|c|c|c|c|}
\hline Kavram & Sayı & Kavram & Sayı \\
\hline İşgal/Işsalci/Zapt Etmek & 4 & & Kılıç & 1 \\
\hline Göç/Göçmen/Mülteci & 4 & & Kanlı Eylem & 1 \\
\hline
\end{tabular}




\begin{tabular}{|c|c|c|c|c|}
\hline Başörtü/Bez Parçası & 4 & Nefret & 1 \\
\hline Kadın & 4 & Kur'an & 1 \\
\hline Terör/Terörizm & 2 & İslamlaştırma & 1 \\
\hline Cihat/Cihatçı & 2 & Saldırı & 1 \\
\hline Erkek & 2 & Korku & 1 \\
\hline Cami/Minare & 2 & İstila & 1 \\
\hline Domuz Eti & 2 & Sömürgeleşme & 1 \\
\hline Haçlı & 1 & Sindirme & 1 \\
\hline Selefizm & 1 & Şeyh & 1 \\
\hline Cinsel Saldırı & 1 & & Helal Gıda & 1 \\
\hline Acımasızlık & 1 & & Para & 1 \\
\hline Sinsice & 1 & Şirket & 1 \\
\hline Aşırıcılar & 1 & Ilahi Metin & 1 \\
\hline Toplam Kavram Sayısı: & & & & \\
\hline
\end{tabular}

Tablo 4'te yer alan verilerden hareketle, i̇slamofobik söylem ile kurgulanan kavramların kullanım sıklığının oldukça fazla olduğu gözlemlenmektedir. Toplam 16 farklı ülkeye ait 16 medya içeriğinde, sıkça işgal, şiddet ve terör anlatımına sahip kavramların kullanımı dikkat çekicidir. Yinelenen bir söylemle kullanılan bu kavramlarla negatif bir i̇slam/Müslüman okuması yapıldığını ifade etmek mümkündür. Kavramların kullanıldığı bağlamlar gözlemlendiğinde bu durumun daha tehditkar bir görünüme sahip olduğu belirtilebilir.

Tablo 5. İslam ve Müslümanlar ile iliş̧kili/ilișkilendirilebilecek Kavramların Kategorik Sinıflandırması

\begin{tabular}{|c|c|c|c|c|c|}
\hline & Kategori & Ka & nlar & Sayı & Oran \\
\hline 1 & $\begin{array}{l}\text { Baskı, Şiddet, Tehdit vb. } \\
\text { Kavramlar }\end{array}$ & $\begin{array}{c}\text { Terör/Terörizm } \\
\text { İşgal/Işgalci } \\
\text { Zapt Etmek } \\
\text { Saldırı } \\
\text { Korku } \\
\text { İstila } \\
\text { Sömürgeleşme } \\
\text { Sindirme }\end{array}$ & $\begin{array}{c}\text { Sinsice } \\
\text { Nefret } \\
\text { Haçlı } \\
\text { Cinsel Saldırı } \\
\text { Kılıç } \\
\text { Kanlı Eylem } \\
\text { Acımasızlık } \\
\text { İslamlaştırma }\end{array}$ & 19 & 40,42 \\
\hline 2 & $\begin{array}{l}\text { Siyasal, Sosyo-Ekonomik } \\
\text { vb. Kavramlar }\end{array}$ & $\begin{array}{c}\text { Göç/Göçmen/ } \\
\text { Mülteci } \\
\text { Selefizm }\end{array}$ & $\begin{array}{l}\text { Para/Şirket } \\
\text { Domuz Eti } \\
\text { Aşırıcılar }\end{array}$ & 10 & 21,27 \\
\hline 3 & İslami Kavramlar & $\begin{array}{l}\text { Kur'an } \\
\text { Cihat/Cihatçı } \\
\text { İlahi Metin }\end{array}$ & $\begin{array}{c}\text { Helal Gıda } \\
\text { Cami } \\
\text { Minare }\end{array}$ & 7 & 14,90 \\
\hline
\end{tabular}




\begin{tabular}{|l|l|c|c|c|c|}
\hline 4 & Cinsiyetçi Söylemler & Kadın & Erkek & 6 & 12,77 \\
\hline 5 & İslami Giyim Görünüm & $\begin{array}{c}\text { Başörtü/ } \\
\text { Bez Parçası }\end{array}$ & Şeyh & 5 & 10,64 \\
\hline \multicolumn{2}{|l|}{ Toplam }
\end{tabular}

Tablo 5'te yer alan kavramlar kategorik olarak Tablo 5'te bir araya getirilmiştir. Kavramlar, tematik okumaya ve anlamsal bağı ortaya çıkarabilecek bir sorgulamaya izin verecek şekilde, metinlerdeki anlatımına paralel olarak belirlenen kategorilere dâhil edilmiştir. Bazı kavramların farklı yerlerde benzer anlamlarda kullanılmasından dolayı, kategorilendirme yapılırken anlamsal kümenin oluşmasına dikkat edilmiștir. Dolayısıyla kavramların tespit edilmesiyle birlikte; psikolojik ve fizyolojik şiddet vb., ve tehdit anlatımlarına vurgu yapan kavramlar "Baskı, Şiddet, Tehdit vb. Kavramlar" kategorisinde; Avrupa'daki Müslümanlara yönelik söylemi taşıyan ve göçmenlere ilişkin vurguyu içeren kavramlar "Siyasal, Sosyo-Ekonomik vb. Kavramlar" kategorisinde; İslam dinine ait kavramlar "İslami Kavramlar" kategorisinde; Müslüman kadınlara ve erkeklere ait kullanılan ve cinsiyetçi söylemin ön plana çıkarıldığı kelime ve kavramlar "Cinsiyetçi Söylemler" kategorisinde; Müslümanların görünümü ve İslami giyim/görünüm unsurları ile ilişkilendirilen kavramlar "İslami Giyim Görünüm” kategorisinde kodlanmıştır. Bu bağlamda medya içeriklerinde baskı, şiddet ve tehdit anlatımlarına vurgu yapan ve İslam'ı, Müslümanları acımasız, tehditkar, terör yanlısı ve şiddet taraftarı olarak gösteren anlatımların oldukça fazla olduğu belirlenmiştir $(\% 40,42)$. Bununla birlikte, Avrupa'da yaşayan Müslümanların Avrupa'nın siyasal, toplumsal ve ekonomik yapısı için bir tehdit oluşturduğuna iliş̧kin, ötekileştirici bir söyleme ve ırkçı bir tonlamaya sahip pek çok anlatıma rastlanmıştır $(\% 21,27)$. Yine, İslam'a ait, cihat, helal gıda, Kur'an gibi kavramların negatif siyasal ve sosyal olaylarla birlikte kullanılarak İslam karşıtı bir söylemin inşa edildiği $(\% 14,90)$, cinsiyetçi söylemler ve İslami giyim/görünüm unsurları ile İslam dinine ve Müslümanlara yönelik olumsuz bir anlatımın üretildiği belirlenmiștir.

Tablo 6. İslam ve Müslümanlar ile İlişkili/ilişkilendirilebilecek Kavram Kategorilerinde Öne Çıkan Temalar

\begin{tabular}{|c|c|c|c|c|}
\hline \multicolumn{2}{|r|}{ Kategoriler } & Temalar & $\begin{array}{l}\text { Sayı } \\
\text { (f) }\end{array}$ & $\begin{array}{l}\text { Oran } \\
(\%)\end{array}$ \\
\hline \multirow{3}{*}{1} & \multirow{3}{*}{$\begin{array}{l}\text { Baskı, Şid- } \\
\text { det, Tehdit } \\
\text { vb. Kavram- } \\
\text { lar }\end{array}$} & $\begin{array}{l}\text { Müslümanlar zapt eden, zor kullanan, güce ve şiddete baş- } \\
\text { vuran kişiler olarak tasvir edilmiştir. İslam'ın, eskisinden } \\
\text { daha güçlü bir şekilde işgal politikalarına sahip olduğu, do- } \\
\text { layısıyla da İslam ve Müslümanlar ile mücadele edilmesi ge- } \\
\text { rektiği anlatımı yapılmıştır. }\end{array}$ & 4 & 14,29 \\
\hline & & $\begin{array}{l}\text { İslam/Müslümanlar terör, işgal ve saldırı kelimeleri ile } \\
\text { birlikte kullanılarak bir tehdit algısı oluşturulmuştur. }\end{array}$ & 2 & 7,14 \\
\hline & & $\begin{array}{l}\text { İslam acımasız, sinsi vb. gibi olumsuz kavramlarla } \\
\text { ilişkilendirilerek, İslam'a yönelik negatif bir okuma yapılmış } \\
\text { ve İslam'a/Müslümanlara karşı gerçekleştirilen nefret } \\
\text { içerikli tutumların haklı olduğu söylemi inşa edilmiştir. }\end{array}$ & 2 & 7,14 \\
\hline \multirow{3}{*}{2} & \multirow{3}{*}{$\begin{array}{l}\text { Siyasal, } \\
\text { Sosyo-Eko- } \\
\text { nomik vb. } \\
\text { Kavramlar }\end{array}$} & $\begin{array}{l}\text { Avrupa'daki göç olayları ve mülteciler ile ilgili meseleler İs- } \\
\text { lam ile ilişkilendirilerek, bu kavramlar üzerinden Müslüman- } \\
\text { ların toplumsal düzeni bozan kişiler olduğu anlatımı kurgu- } \\
\text { lanmıştır. }\end{array}$ & 4 & 14,29 \\
\hline & & $\begin{array}{l}\text { İslami hassasiyete sahip kişilerin yaşam biçimleri (beslenme } \\
\text { alışkanlıkları ve ekonomik tercihleri) ötekileştirici bir bakış } \\
\text { açısıyla yorumlanmıştır. }\end{array}$ & 3 & 10,72 \\
\hline & & $\begin{array}{l}\text { İslam, radikal düşünce, kişi/grup ve olaylarla } \\
\text { ilișkilendirilmiştir. }\end{array}$ & 2 & 7,14 \\
\hline
\end{tabular}




\begin{tabular}{|c|c|c|c|c|}
\hline \multirow{2}{*}{3} & \multirow{2}{*}{$\begin{array}{l}\text { İslami } \\
\text { Kavramlar }\end{array}$} & $\begin{array}{l}\text { Cihat kelimesi çeşitli terör örgütleri ile ilişkilendirilerek kul- } \\
\text { lanılmakta ve korku oluşturulmaktadır. }\end{array}$ & 2 & 7,14 \\
\hline & & $\begin{array}{l}\text { Kur'an-ı Kerim'in ve çeşitli dini kavramların ekonomik gelir } \\
\text { elde etme ve sömürü amacıyla kullanıldığı belirtilmiştir. }\end{array}$ & 1 & 3,57 \\
\hline \multirow{2}{*}{4} & \multirow{2}{*}{$\begin{array}{l}\text { Cinsiyetçi } \\
\text { Söylemler }\end{array}$} & $\begin{array}{l}\text { İslam'ın acımasızlık derecesinde eril bir din olduğu } \\
\text { vurgulanmış, bu durumun da Batı için tehlikeli olduğu } \\
\text { uyarısında bulunulmuştur. }\end{array}$ & 2 & 7,14 \\
\hline & & $\begin{array}{l}\text { Başörtülü kadınların uzak durulması gereken, sosyal yaşamı } \\
\text { tehdit eden kişiler olduğu vurgusu yapılmıştır. }\end{array}$ & 2 & 7,14 \\
\hline \multirow{2}{*}{5} & \multirow{2}{*}{$\begin{array}{l}\text { İslami Giyim } \\
\text { Görünüm }\end{array}$} & $\begin{array}{l}\text { İslami giyim/görünüm unsurlarının tehlikeli olduğu ve } \\
\text { dolayısıyla toplumsal düzeni bozduğu söylemi inşa } \\
\text { edilmiştir. }\end{array}$ & 3 & 10,72 \\
\hline & & $\begin{array}{l}\text { İslami giyim/görünüm unsurlarının propaganda, istila, } \\
\text { sömürge ve işgalin birer simgesi olduğu iddia edilmiştir. }\end{array}$ & 1 & 3,57 \\
\hline & Toplam & & 28 & 100 \\
\hline
\end{tabular}

Tablo 6'da yer alan bulgulara göre, İslam ve Müslümanlar ile ilişkili/ilişkilendirilebilecek 28 ana tema tespit edilmiştir. Temaların belirlenmesinde cümle anlatımı ve kelime kullanımı göz önüne alınmıştır. Bu bağlamda, baskı, şiddet, tehdit vb. kavramların kullanımı ile en çok; Müslümanların zapt eden, zor kullanan, güce ve şiddete başvuran kişiler olarak tasvir edildiği, İslam'ın tehditkâr bir görünüme sahip olduğu anlatımı yapılmıştı $(\% 14,29)$. Bununla birlikte İslam dininin terör ve şiddeti desteklediği $(\% 7,14)$, İslam'a ve Müslümanlara yönelik negatif anlam ve anlatımların haklı olduğu vurgusu yapılmıştır $(\% 7,14)$. Baskı, şiddet, tehdit vb. kavramlar ile ilgili kullanılan yazılara ilişkin şu cümleleri örnek vermek mümkündür:

“íslam Atina'yı İşgal Etti. Noel'de Terör Saldırısı Korkusu” (Yunanistan); “Müslümanlar Çek Yargısını Zapt Ediyor” (Çekya); “islam’a karşı yapısal nefret' üzerine abartılı sonuçlar çıkaran herkes yanılmaktadır." (Avusturya); "sokağın İslamlaştırılması..." (Fransa).

Siyasal, sosyo-ekonomik vb. kavramlar ile birlikte ön plana çıkarılan temaların başında ise Avrupa'daki Müslümanların toplumsal düzeni bozduğu, göçmenler ile ilgili sosyal, siyasal ve ekonomik olayların İslam ile ilişkili olduğu anlatımı gelmektedir $(\% 14,29)$. Bununla birlikte, İslami hassasiyete sahip kişilerin ötekileştirilmesine yol açan $(\% 10,72)$ ve İslam'ı/Müslümanları negatif anlamlarla kurgulanan radikal düşünce, kişi/grup ve olaylarla ilişkilendiren anlamın inşa edildiği $(\% 7,14)$ belirlenmiştir. Bu anlatıma yol açan cümleler ile ilgili şu örnekleri vermek mümkündür:

"Cinsel saldırı davalarının göçün sonucu olduğunu iddia ederek "Çok fazla mülteci kabul ettik” (Finlandiya); “...göç, bütünleşme, sindirme’ ifadelerinin yerini artık 'istila, sömürgeleşme, işgal aldı” (Fransa); “Kur'an'dan para emen dev Müslüman şirketi” (Romanya) “... helal gıda bulunması ihtimalini kınamış, çocukların eşit olmayan şartlarda muamele gördüğünü iddia etmiş ve okulun Müslüman çocukları için domuz eti bulunmayan yiyecek seçenekleri sunduğunu kaydetmiştir" (Slovenya); “Gündüz Bakımevi Domuz Etini Menüden Çıkardı” (Almanya); “... okulun Selefizm ile bağlantılı..." (Hollanda); "Așırıcıların Yeni Büyük bir Cami ve Gençler için Din Değiştirme Merkezi Planını Durduracak mı?” (Norveç).

İslami kavramların anlatımında ise benzer temaların ön plana çıkarıldığı belirlenmiştir. Özellikle İslami kavramların ön yargıya dayalı oryantalist bakış açısıyla yorumlandığı belirlenmiş, özellikle cihat kelimesinin dini anlamından/anlatımından uzak bir şekilde yorumlandığı tespit edilmiştir. Negatif bir şekilde kurgulanan İslami kavramların kullanımı ile ilgili şu cümleler örnek gösterilebilir: 
"Sponsoru Kur'an olan takımın rakibi..." (Romanya); "Bosna Hersek'e Cihatçları Getirdi” (Sırbistan); “Bosna Hersek'e Yüzlerce Cihatçı Geliyor” (Bosna Hersek) “Bir ilkokulda helal gıda bulunması ihtimalini kınamış..." (Slovenya).

Cinsiyetçi söylemler ise yine İslam'a ve Müslümanlara karşı beslenen ön yargıyı ve tehdit algısını taşımaktadır. Bu yazılarda, i̇slam'ın negatif anlatımla eril bir din olduğu vurgusu yapılmış, kadınların başörtülü olması veya kadınların/erkeklerin giyimleri tehditkar bir şekilde yorumlanmış. Bu anlatımlara ilişkin şu cümleler örnek gösterilebilir:

“islam'ın “(dişileşmiş Avrupa'ya karşı) acımasızlık derecesinde eril olduğu ve 'kadın' Avrupa'ya sinsice yanaşmak için yapılan ortak bir hareket..." (Hırvatistan); "Sokaktaki başörtülü kadınlar, ihramlı erkekler aslında propagandadır" (Fransa).

İslami giyim/görünüm unsurları ile ilgili yazılarda ise çoğunlukla Müslümanların görünümlerinin tehdit edici olduğu ve toplumsal düzeni bozduğu şeklindeki nefret dili ile ötekileştirici, kategorileştiren bir anlatım kurgulanmıştır. Bu anlatımlara ilişkin şu cümleleri belirtmek mümkündür:

“Bir bez parçasının önemi. Bizi başörtüsünün zararsız olduğuna inandırmak isteyenler, tam olarak kadınların haysiyetinin her şeyden önce geldiğini, gerekirse tüm ilahi metinlerin üzerinde olduğunu anlamayanlardır." (İspanya); "Okullarımızda Başörtülü Müslüman Kadınlar Olacak" (Çekya); "Sokaktaki başörtülü kadınlar...” (Fransa); "Yetkililer tarafından bir şeyhe satılan..." (Romanya).

Tablo 7. İslam ve Müslümanlar İle Illişkili/ilişkilendirilebilecek Kavram Kategorilerinin Anlatım Niteliği ve Anlatım Biçimi

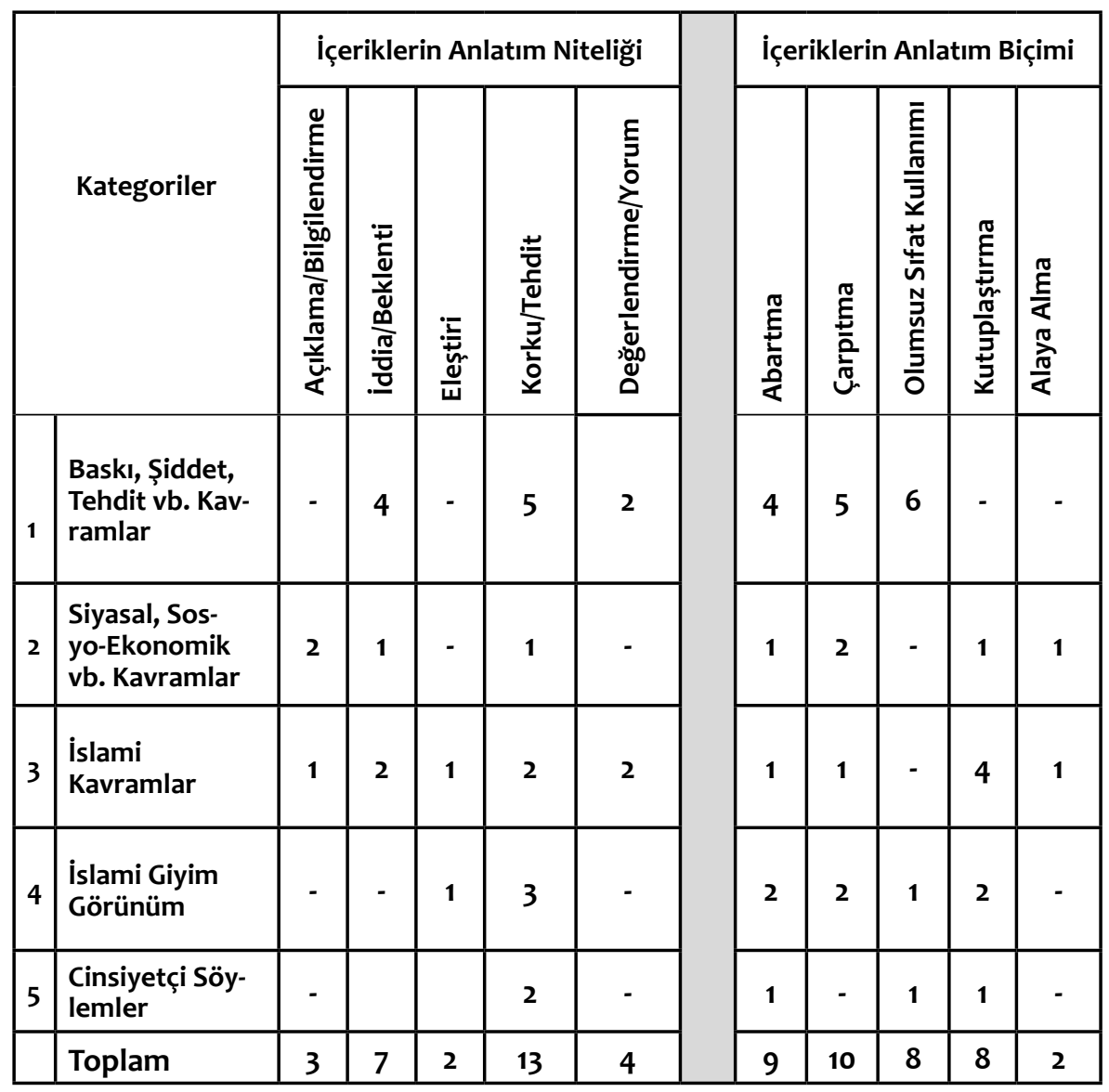


Tablo 7'de kategorilendirilen kavramların anlatım niteliğine ve anlatım biçimine yer verilmiştir. Bu bağlamda, kavramların anlatımında çoğunlukla korku/tehdit ve iddia/beklenti söyleminin kullanıldığı tespit edilmiștir. Dolayısıyla kavramların bağlamından koparılarak, manipüle amaçcı kullanıldığını ifade etmek mümkündür.

Ayrıca kavramların anlatım biçiminde çarpıtmanın, abartmanın, olumsuz sıfatların ve kutuplaştırmanın fazlaca yer aldığı belirlenmiştir. İslam/Müslümanlar ile ilişkilendirilerek kullanılan kavramların bu tonlamalarla aktarılması, ayrımcılığa, ötekileștirmeye, dışlamaya, yabancı düșmanlığına ve kültürel ırkçılığa sebep olabilecektir.

Tablo 8. İslam ve Müslümanlar ile illişkili/ilişkilendirilebilecek Kavram Kategorilerindeki Görseller

\begin{tabular}{|c|c|c|c|}
\hline \multicolumn{2}{|r|}{ Kategoriler } & $\begin{array}{l}\text { Görsel } \\
\text { Sayısı }\end{array}$ & Görselin İçeriği \\
\hline 1 & $\begin{array}{l}\text { Baskı, Şiddet, Tehdit vb. } \\
\text { Kavramlar }\end{array}$ & 2 & $\begin{array}{l}\text { Kılıç, Cami, Brenton Tarrant (Yeni Ze- } \\
\text { landa Christchurch Cami saldırganı), } \\
\text { Protesto Görüntüsü }\end{array}$ \\
\hline 2 & $\begin{array}{l}\text { Siyasal, Sosyo-Ekonomik } \\
\text { vb. Kavramlar }\end{array}$ & 2 & Gazeteci, Okul \\
\hline 3 & İslami Kavramlar & 4 & $\begin{array}{c}\text { IŞid Militanları, Işid Bayrağı, Politikacı } \\
\text { (Angela Merkel), Cami Karikatürü, İsla- } \\
\text { mi Bayrak Taşıyan Askerler }\end{array}$ \\
\hline 4 & İslami Giyim Görünüm & 2 & Yazar, Başörtüsü \\
\hline 5 & Cinsiyetçi Söylemler & 1 & Gazeteci \\
\hline \multicolumn{4}{|c|}{ Toplam 11} \\
\hline
\end{tabular}

16 Avrupa ülkesine ait medya içeriğinde yer alan 11 görselin genellikle siyasal/sosyal olaylarla ilişkili olduğu belirlenmiştir. Bununla birlikte görsellerde uzman ve politikacı görüşlerine de yer verilmiştir.

Fakat bazı kavram kategorilerinde kullanılan görseller İslam'a ve Müslümanlara yönelik anti-i̇slamist oryantalist bakış açısının izlerini taşımaktadır:

Resim 1. Arnavutluk, Ora News Televizyon Kanalı

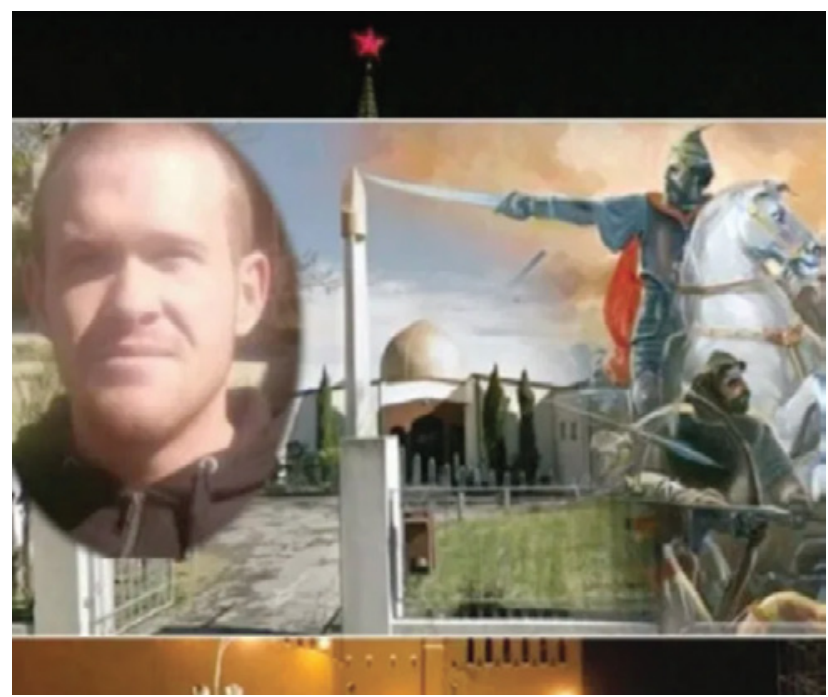


Görselde, Arnavut ulusal kahramanı Scanderbeg (İskender Bey), kılıcıyla bir minareye işaret etmektedir.

Resim 2. Bosna Hersek, Novosti RS Gazetesi

\section{Stiže na stotine džihadista u BiH!}

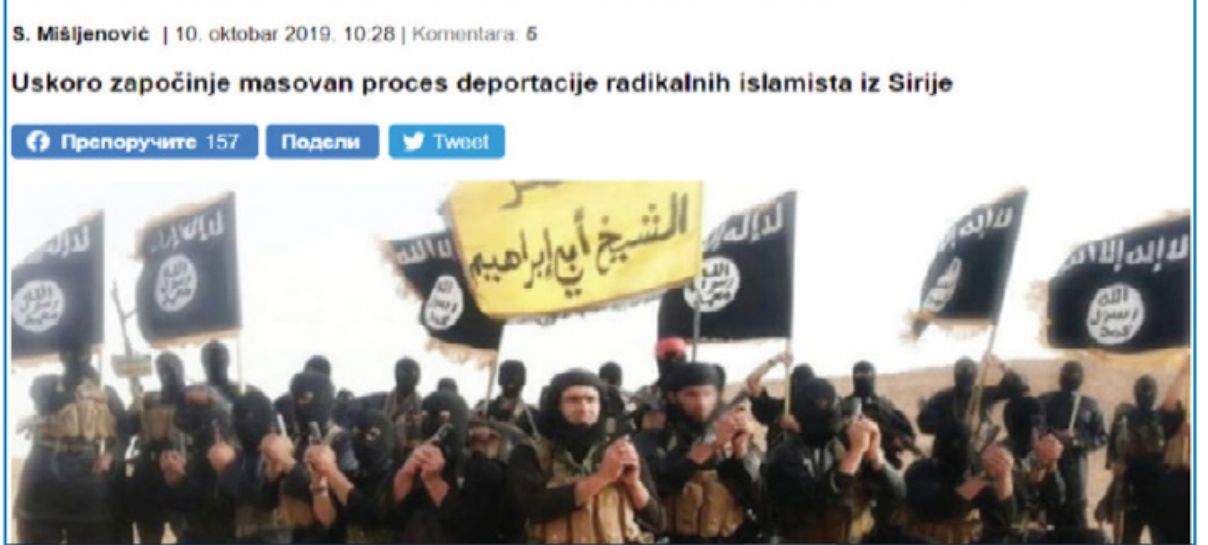
tadır.

Haberin başlığında, “Bosna Hersek’e Yüzlerce Cihatçı Geliyor” ibaresi yer almak-

Resim 3. İspanya, El Pais Gazetesi

\section{La importancia de un trozo de tela}

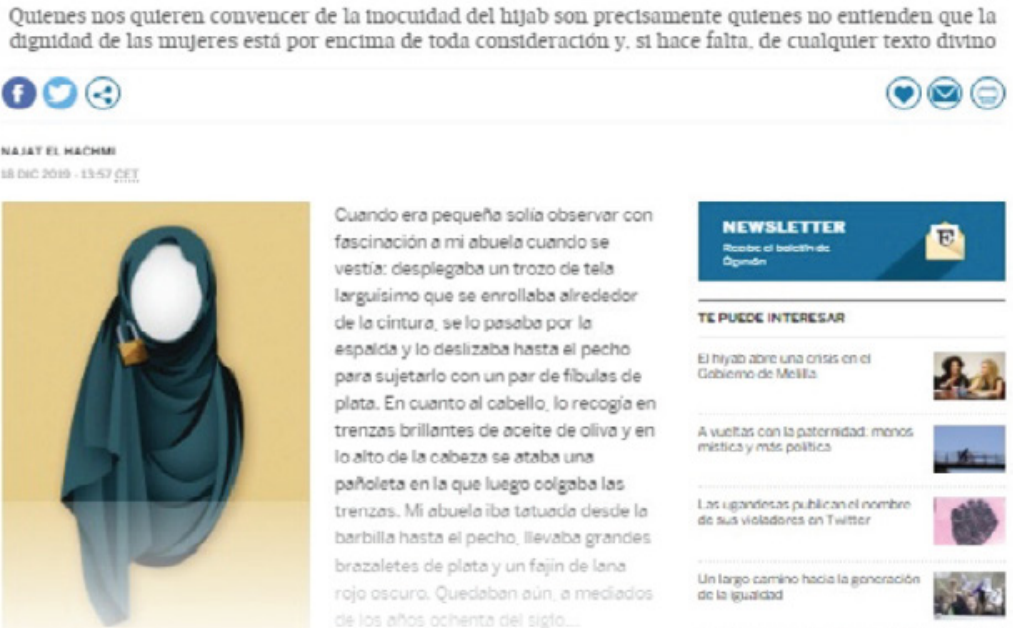

Gazetede, "Bir bez parçasının önemi. Bizi başörtüsünün zararsız olduğuna inandırmak isteyenler, tam olarak kadınların haysiyetinin her şeyden önce geldiğini, gerekirse tüm ilahi metinlerin üzerinde olduğunu anlamayanlardır" cümlesine yer verilmiștir.

Görülebileceği üzere, çeşitli siyasal, sosyal olaylar üzerinden İslam/Müslüman okuması yapılmakta; İslam ile ilişkili kavramlar anlamsal bağlamından koparılarak ön yargı ile çerçevelenmiş negatif terör, şiddet, özgürlük karşıtı gibi söylemlerle bir arada gösterilmektedir. Bu durum İslamofobik eylemlere yol açabilecek politik ve toplumsal bir dil de üretmektedir. 


\section{Genel Değerlendirme ve Sonuç}

Küresel bir problem haline gelen İslamofobinin artış göstermesinde kitle iletişim araçlarının önemli bir rolü bulunmaktadır. Özellikle Avrupa'daki medya organlarının içeriklerinde İslam ve Müslüman temsilinin negatif görünürlük kazanması, bilhassa Müslüman nüfusun fazla olduğu Avrupa ülkelerindeki İslam karşıtlığını körüklemekte ve Müslümanlara yönelik sosyal ortamlarda İslamofobik olay ve tutumların meydana gelmesine neden olabilmektedir. Söz konusu problem ayrıca Batılı ülkelerde yaşayan Müslüman nüfus için de bir kimlik problemi ortaya çıkartmakta; kendilerine, inançlarına ve başkalarına karşı sorumluluklarına dair ilişkisel süreçleri çok daha çetrefilli bir hale getirmektedir (Eken, 2020, s. 44-47).

Bu bağlamda Avrupa'daki bazı ülkeleri örneklem alarak bu ülkelerdeki medya ve İslam ilişkisini inceleyen "European Islamophobia Report 2019" isimli raporda yer alan medyatik verilerdeki İslamofobik söylemler incelenmiștir. Nitel yönelimli içerik analizinin kullanıldığı çalışmada araştırma sorularından hareketle şu veriler elde edilmiştir:

1. İslamofobik söylemlerin kitle iletişim araçlarının birçok türünde kullanıldığı, yazılı ve görsel içeriklerle İslam karşıtlığının yaygınlaştırıldığı belirlenmiştir.

2. Avrupa medyasında İslam ve Müslümanlar ile ilişkili birçok kavramın kullanıldığı, kullanılan bu kavramların ise tamamının negatif bir görünüme sahip olduğu tespit edilmiştir.

3. Medya içeriklerinin çoğunlukla, i̇slam'ın ve Müslümanların baskıcı, şiddet taraftarı olduğu ve Müslümanların toplumsal yapı için bir tehdit unsuru olduklarına yönelik anlatımlar içerdiği; Avrupa'nın İslam ve Müslüman tehdidine karşı dikkatli olması gerektiği ve Müslümanlara yönelik ötekileştirici, kutuplaştırıcı ve ırkçılığa da sebep olabilecek söylemlerin kurgulandığı gözlenmiştir.

4. İslam ve Müslümanlar ile ilgili medyada korku içerikli/tehdit edici bir dilin kullanıldığı ve olayların çarpıtılarak ve abartılarak sunulduğu ortaya çıkmıştır.

5. Kullanılan görsellerle, negatif kavramları destekleyen bir anlatım inşa edilmiş, özellikle İslami kavramlar siyasal, sosyal olaylar ile ilişkilendirilerek İslam dininin ve Müslümanların terör ve şiddet taraftarı olduğu şeklinde bir kurgu üretilmiştir.

Araştırma kapsamında, yazılı ve görsel medyada, internet gibi bilgi erişiminin ve yayılımın daha fazla olduğu iletişim araçlarında; İslam ve Müslümanlara yönelik tarihsel süreçten beslenen negatif ve İslam karşıtlığı içeren ifadelerin sıkça kullanıldığı belirlenmiştir. Günümüzde medya araçlarının hedef kitlesinin çok geniş olduğu ve kitle iletişim araçlarının temel bilgi kaynağı olduğu düşünüldüğünde, bu anlatımların bireyler üzerinde nasıl bir etki bırakacağı aşikârdır.

İslamofobinin siyasal, sosyal, ekonomik ve kültürel her alana yayılan bir problem olması sebebiyle, medyanın de bu hususta üretmiş olduğu İslamofobik söylemlere karşı bir çözüm getirilmesi önemli bir gerekliliktir. Dolayısıyla bu çalışmada, İslamofobinin görünümüne ve artış göstermesindeki etmenlere odaklanarak, İslamofobi probleminin çözümü hususunda yapılacak siyasal, sosyal ve kültürel politikalara, çalışmalara katkı sağlayacaktır.

\section{Son Notlar}

'Özellikle Siyaset, Ekonomi ve Toplum Araştırmaları Vakfı (SETA) tarafından 2015 yılından itibaren hazırlanan 'European Islamophobia Report' isimli araştırma verilerini içeren ve İslamofobinin mevcut durumunu geniş bir örneklem çerçevesinde ele alan raporlar ayrı bir önem taşımaktadır. 


\section{Kaynakça}

Alver, F. (2000). Medya aracılığıyla yabancıyla karşılaşmanın gerçekliği. İstanbul Üniversitesi Iletişim Fakültesi Dergisi, 71-84.

Bal, H. (2013). Nitel araştırma yöntemi. Isparta: Fakülte Kitabevi.

Chelimsky, E. (1989). Content analysis: A methodology for structuring and analyzing written material. United States General Accounting Office

Cottle, S. (2000) Ethnic minorities and the media: Changing cultural boundaries, Buckingham: Open University Press.

Eagleton, T. (1996). İdeoloji. İstanbul: Ayrıntı Yayınları.

Eken, M. (2020). Modern görsel kültürde M Nesli'nin online inanç pratikleri. Bilimname (43), 31-71. DOI: 10.28949/bilimname.762744

Esposito, J. L. (2013). İslamofobi ve çok kültürlülük. Hukuk ve Medya Bağlamında Tarabya Uluslararası İslamofobi Konferansı (s.27-31). İstanbul: T.C. Başbakanlık Basın Yayın ve Enformasyon Genel Müdürlüğü.

European Islamophobia Report. (2019). Editörler: Enes Bayraklı ve Farid Hafez. Ankara: SETA. Erişim Adresi: https://www.islamophobiaeurope.com/wpcontent/ uploads/2020/06/EIR_2019.pdf https://www.setav.org/medyada-islamofobi-eir2019/

Geray, H. (2006). Toplumsal araştırmalarda nicel ve nitel yöntemlere giriş. Ankara: Siyasal Kitapevi.

Gökçe, O. ve Gökçe, G. (2015). İslam ve Avrupa. Konya: Çizgi Kitabevi.

Hassan, I., Azmi, M. N. ve Abubakar, U. I. (2017). Framing Islam in news Reporting: A comparative content analysis. Asian Social Science, 13, (10), 112-119.

Lean, N. (2015). İslamofobi endüstrisi. Ankara: Diyanet İşleri Başkanlığı Yayınları.

Neuman, W. L. (2014). Toplumsal araştırma yöntemleri 2. (Çev. Sedef Özge) Ankara: Yayınodası Yayınları.

Poole, E. (2003). Islamophobia. Ellis Cashmore (Ed.). Encyclopedia of race and ethnic studies (s. 47-66) içinde. Routledge.

Said, E. W. (2008). Medyada İslam. (Çev. Aysun Babacan). İstanbul: Metis Yayınları.

Sözen, E. (1999). Söylem. İstanbul: Paradigma Yayıncılık.

Uluç, G. (2009). Medya ve oryantalizm. İstanbul: Anahtar Kitaplar.

Yaylagül, L. (2012). 12 Haziran 2011 seçimlerinin gazetelerde sunumu. Erciyes iletişim Dergisi "akademia", 2(4), 2-22.

Yıldırım, B. (2015). İçerik çözümlemesi yönteminin tarihsel gelişimi ve uygulama alanları. Besim Yıldırım (Ed.), iletişim Araştırmalarında Yöntemler içinde (s. 105154). Konya: Literatürk Yayınları. 


\title{
MEDIAD \\ Medya ve Din Araştırmaları Dergisi | Journal of Media and Religion Studies
}

\section{Traces of Anti-Islamic Discourses in European Media}

\author{
Mustafa TEMEL \\ Ömer Faruk KOÇAK
}

\section{Extended Abstract}

While Islam is presented with cliché representations and introduced negatively on media tools, such as newspapers, magazines, television, and the internet, positive images regarding Islam and Muslims are not provided in the media (Lean, 2015, p. 136). Maintained especially by traditional media and originating from historical prejudice and discrimination, such statements have changed form and have become more common with the development of internet technologies. Based on this image established by the internet, Islam was associated with the actions of a certain group of people and presented unilaterally. The contents produced in social media tools appeared after the development of the internet by people/ organizations with prejudice against Islam, caused an increase in Anti-Islamic discourses. In this respect, it is considered that social media is more effective than the traditional media in increasing anti-Islamic attitudes and actions (Esposito, 2013, p. 29-30).

As it is seen, mass media have an apparent and significant effect on the increase of Islamophobia, referring to fear based on prejudice and discrimination against Islam and Muslims, becoming a global problem.

In this regard, Anti-Islamic attitudes and Islamophobic actions, resulting in discrimination, marginalization, exclusion in political, social/cultural and economic fields, based on xenophobia and institutionally associating with cultural racism, containing hate speech, relate to a field that should be studied within the perspectives of many disciplines. However, when considering the power of media tools in determining/managing attitudes and perceptions, the effect of the media in the mentioned anti-lslamism is an issue that needs to be discussed.

Negative presentation of Islam and Muslims, especially in the contents of media organs in Europe increases the Anti-Islamism particularly in the European countries with a large Muslim population, and may cause Islamophobic events and attitudes against Muslims in social environments.

In this study, the representation of Islam/Muslims was questioned and it was aimed to provide a communicative perspective regarding the solution of Islamophobia, which has become a global political, social, cultural, economic, and theological problem. In this respect, the representation of Islam in European media was examined, anti-Islamic discourses that may occur as a result of this representation were discussed, and a perspective on the effect of the media on the increasing Islamophobic actions in Europe was provided in this study in which content analysis method was utilized. In this regard, the followings were achieved by qualitative content analysis after examining the Islamophobic discourses in media data 
included in the report named after "European Islamophobia Report 2019", discussing the relationship between media and Islam in some European countries by using these countries as a sample:

1. It has been determined that Islamophobic statements are used in many mass media tools and anti-Islamism are expanded by written and visual contents.

2 . It has been determined that many terms related to Islam and Muslims are used in the European media, and all of these terms used to have negative contents.

3. It has been specified that the media contents mostly involved statements on the fact that Islam and Muslims are oppressive and supporting violence and Muslims are a threatening factor against the social structure, in this respect, discourses are expressing that Europe should be careful against the threat of Islam and Muslim, and marginalizing, polarizing and causing racism against Muslims.

4. It has been achieved that a fearful/threatening language is used for Islam and Muslims in the media, and events are presented by being twisted and exaggerated.

5. It has been produced a discourse supporting negative concepts by the visuals used, and Islamic terms have been associated with political, social events, and Islam and Muslims are a supporter of terror and violence.

It has been achieved in this study that the statements caused by historical process regarding Islam and Muslims, having negative manner and including anti-Islamism are used frequently in many print and visual media as well as in communication tools such as the internet where information access and dissemination is more. Today, when considering that media tools have a very large target audience and mass communication tools are primary information sources, it is clear that how an effect these statements will have on individuals.

As Islamophobia has become a problem which expanded to political, social, economic, and cultural areas, it is of importance to find a solution for Islamophobic discourses produced by media in this respect. Accordingly, this study would contribute to political, social, and cultural policies and studies to be done to solve the problem of Islamophobia by underlining the factors related to appearance and increase in Islamophobia.

Bu makale iThenticate yazılımıyla taranmıștır. Intihal tespit edilmemiştir. This article has been scanned by iThenticate. No plagiarism detected.

$* * * * * * * * * * *$

Bu çalıșmada “Yükseköğretim Kurumları Bilimsel Araștırma ve Yayın Etiği Yönergesi” kapsamında uyulması belirtilen kurallara uyulmuştur.

In this study, the rules stated in the "Higher Education Institutions Scientific Research and Publication Ethics Directive" were followed. 